\title{
A. A. Maiorov \\ Management of a higher education institution and ways to implement effectively its innovation policy
}

\section{KEYWORDS}

education;

management;

information technology;

management technologies;

innovative technologies

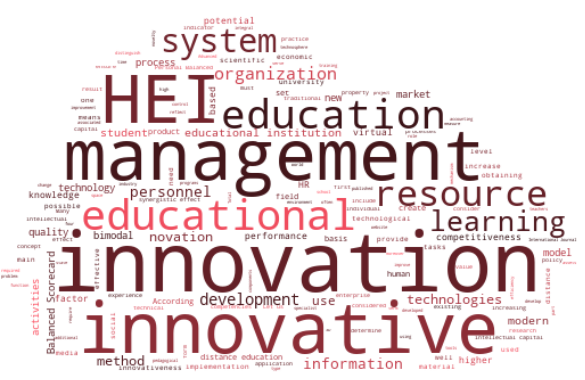

Word Cloud Generated by:

https://wordscloud.pythonanywhere.com/

\section{ABSTRACT}

Introduction. The utilization of innovation activity mechanisms increases the competitiveness and quality of educational services. The necessity to develop an innovative environment, to intensify the innovative activity of higher education institutions determines the relevance of research in the field of innovative management.

The purpose of the article is to identify ways to implement effectively the innovation policy of a higher educational institution.

Materials and methods. A theoretical analysis of research materials (data of ratings of technological innovations in education, publications in periodicals, conference proceedings, and analytical materials) was used.

Results. The main innovative educational factors and technologies were identified: educational virtual and media technologies, human resource management, balanced scorecard as an innovative technology, bimodal educational systems.

Discussion. The main functions of the educational knowledge management system are in solving interrelated problems: in the formation of innovative and self-learning corporate human capital; in social conditions, within which this capital realizes itself in the creation of innovations demanded by the market and other consumers in the form of educational products.

Maiorov, A. A. (2021). Management of a higher education institution and ways to implement effectively its innovation policy. Economic consultant, 34 (2), 42-51. doi: 10.46224/ecoc.2021.2.5 


\section{INTRODUCTION}

T

he development of education is required to solve the problems of socio-economic development of states and is one of the highest priorities.

The economic conditions of many countries lead to the necessity of financial selfsufficiency of higher education institutions (HEIs). This is due to a decrease in state funding for scientific research and educational programs.

Many HEls strive for the commercialization of educational and scientific activities and for the ability to create and use the results of scientific and technical creativity. Educational and scientific products manufactured by an HEI must be innovative and competitive.

The utilization of innovative activity mechanisms increases the competitiveness and quality of educational services. A modern $\mathrm{HEI}$ is able to ensure the promotion of innovative projects from a concept to implementation independently or in association with other HEls or commercial enterprises. Solving the problem of increasing the efficiency of education necessitates the development of a strategy for optimizing the management control over an HEl. Consequently, modern activities of HEls must organically include innovative activities. Modern trends in the development of higher education reflect the transition of HEls from the classical model of education to an innovative model of education. The problem of managing innovative processes in the educational environment arises in connection with these trends. By transforming the typification of innovations [1] into education, it is possible to single out the following factors influencing the innovation and innovation management: organizational, technological, motivational, informational, intellectual, and technical. The need to develop an innovative environment, to intensify the innovative activity of HEls determines the relevance of research in the field of innovative management.

The purpose of the article is to identify ways to implement effectively the innovation policy of a higher educational institution.

\section{MATERIALS AND METHODS}

The data from the ratings of technological innovations in the field of education (Advanced Micro-Electronics; Spring Wise) as well as the publications in the periodicals Distance and Virtual Learning, European Researcher, Global Journal of Flexible Systems Management, International Journal of Higher Education, Computer Assisted Language Learning, International Journal of Emerging Technologies in Learning, Bulletin of the Moscow Regional Pedagogical University, International Journal of Human Resource Management, Journal of Social Entrepreneurship, Measuring Business Excellence, etc., 
as well as analytical materials and conference proceedings, were used as the materials of the study.

\section{SOURCES}

Unfortunately, nowadays it is typical when any new or even old technology is associated with the term "innovative" and innovation is announced formally. There is a practice to call any new development an innovation without analyzing its characteristics and moreover, the properties defining it as an innovation.

A number of websites have appeared on which various ratings of innovations in education are published. For example, a list of six best technological innovations capable of major changes in education is published on the website of the Advanced Micro-Electronics company:

1. Virtual reality (VR) in education. With VR, students can learn while interacting with the 3D world.

2. Artificial intelligence and machine learning. Adaptive programs considering the individual needs of students have been developed due to machine learning. Artificial Intelligence Tutors have been designed to educate students.

3. Cloud computing for education. This technology grants access to educational resources from anywhere in the world.

4. 3D printing. 3D printing is used for developing prototypes by prospective engineers and designers in HEls.

5. Social networks in educational institutions. Students use them to share information with other students and teachers as well.

6. The use of biometrics in schools. The introduction of biometric systems in schools is utilized to monitor student attendance [2].

The Spring Wise website has published the TOP 7 innovations in education (2020). Let us consider the first three innovations in the article.

1. The iClassroom virtual classroom is used to enhance virtual learning during the COVID-19 pandemic. The platform allows learning communities to interact with each other, share resources, and track progress in selected courses without the need for multiple communication tools.

2. Free street lessons for children from low-income families who do not have access to the Internet or cannot afford digital learning tools.

3. "School-tree" modular educational center, consisting of two circular buildings that combine internal and external space. Classrooms are well ventilated and social distancing is achieved through the extra spaces included in the design [3].

In foreign countries, the Oslo Manual is used as a fundamental document. Let us consider the difference between the concepts of novation and innovation [5] in 
accordance with this guideline adopted by the Organization for Economic Co-operation and Development (OECD) [4].

An obligatory property of innovation is novelty. This means that the main four types of innovations: product, process, marketing, or organizational must be new in relation to the known and applied developments. However, this property is not the only one. Many objects with this property are not innovations, but novations.

Novation is a kind of pioneer product that did not exist before. According to civil law, novation means an agreement of the parties to replace one obligation concluded by them with another obligation [8]. Novations are the most important components of innovations, but they are not identical to them. Not every set of novations is also an innovation. Novation has a certain positive effect, but, as a rule, less in importance and scale than innovation. Let us define innovation from these positions as an integral set of novations that provide an additional effect to the sum of the effects of novations that make it up. An innovation differs from a novation in its larger scale, a larger effect, and the possible presence of a synergistic effect.

Innovation is new to a market (industry). In this case, an organization introduces an innovation that contains signs of innovation in its market (industry) for the first time. Innovation is at a global level when the organization first introduced the innovation to all markets and industries, both domestic and international. New in the world implies a qualitatively higher degree of novelty than new to the market. A situation should be noted when the creators of scientific or technological projects often unreasonably attribute to themselves the level of novelty, only because their project has not been previously applied in the industry or at the enterprise.

Modernization and optimization of managerial control over higher education require an analysis of experience and practical recommendations for HEls in order to select the most effective and optimal solutions for the implementation of the developed strategy [6].

Sharma and Sharma propose a conceptual innovative structure for an educational institution to achieve competitive advantages over other HEls and a high level of academic performance through the interaction of various innovations: innovative ideas and their implementation, teamwork, innovations in the educational process, management, cooperation, etc. [7].

According to Kravchenko et al., one of the tasks of a modern university is to develop the potential of all participants in the pedagogical process, providing them with opportunities to reveal their creative abilities. The authors distinguish the following elements of innovation in HEls: target (increasing the efficiency of resource use in HEIs), contensive (processes of development and application of innovations), and effective (quality of training of the graduates) [8].

Zabolotniaia et al. consider the possibilities of application of the Moodle Learning Management System (LMS) tools to ensure the effective implementation of the innovation policy of a higher educational institution. According to scientists, Moodle LMS provides 
a comprehensive educational process through extensive educational content, a system of control, monitoring, and assessment of the quality of knowledge [9].

Thus, the necessity to improve measures to modernize the management of HEls in the university environment, to provide the informational and methodological support for specialists and administrative and management personnel involved in the modernization of management processes, as well as to improve the qualifications of specialists and management personnel in the field of modern university management, require appropriate justification. Such justification is possible on the basis of studying the practice and experience of existing management solutions using information and communication technology.

The main directions of innovative management in the field of education can be identified as follows:

- the HEl should have its own innovation policy in which all faculty members should take part;

- it is required to understand the role of the HEI in the innovation process;

- the HEl should create and enhance its innovativeness;

- the HEl should apply the innovative methods and technologies;

- the HEI should carry out research activities, obtain and formalize the result in a form suitable for subsequent commercialization; at the same time, the HEI should sell developments, not commercial products;

- the HEl should have a coordinating body that is responsible for innovation policy;

- the HEl should obtain and use the information educational resources for educational tasks;

- the HEl should develop technologies for obtaining and transferring knowledge in educational and management processes.

In the process of teaching and management, educational information models and educational information technologies are based on the use of information units as components of technologies and the basis of information resources.

\section{RESULTS}

\section{Let us list the main innovative educational factors and technologies.}

\section{Educational virtual and media technologies}

Media education - an innovative technosphere is considered as a significant factor in increasing the effectiveness of additional technical education, its role and place in the general system of modernized education. The technosphere is a part of the pedagogically organized space of vocational education institutions, the values of which are becoming modern technical means of information. Media education as an innovative technosphere is a relevant factor in modern education. The advantage of this approach is the ability to integrate a variety of media into one application, for example, sound, video, and text can be presented simultaneously on a Web page. A special type of media resource is virtual educational resources $[10 ; 11]$. 


\section{Human resource management}

The growth of the intellectual capital of the educational institution and the innovativeness of the staff and the $\mathrm{HEI}$ as a whole can serve as a criterion for the innovativeness of an educational institution. Personnel accounting is a formal procedure that does not reflect the innovativeness of personnel, the competitiveness of personnel and does not determine the relationship between the quality of education and personnel.

Increasing the competitiveness of an educational organization is possible through research and development of mechanisms for the formation of the competitiveness of an educational organization based on the organization of intellectual resources [12].

Intellectual factors are associated with the need for human resource (HR) management [13]. Many foreign organizations have the position of HR Director, Head of HR Department, or HR Manager. Russian education lacks such types of management. HR management and personnel management are essentially different technologies. It is HR and its management that create intellectual capital, which is not included in the field of personnel accounting and bookkeeping.

Intellectual capital should be taken as a new economic category that reflects the objective reality of an increase in the value of intangible assets partially amenable to accounting. Other factors of intellectual capital (highly qualified employee, work, pedagogical experience) are not accountable, moreover, they are not even the property of the organization that owns them. These factors affect the market capitalization of a company or the brand of an educational institution. The market value of such an organization exceeds the book value of fixed assets, material and financial assets. On the other hand, this situation creates additional difficulties in managing such capital, since a highly qualified specialist and brand carrier can leave the HEI.

HR management ensures the growth of personnel competencies. Competencies are the foundation of innovation. Competence determines the level and intellectual potential of the personnel and the enterprise. According to the EFE's "Glossary of labor market terms, standards development..." [14], there are four models for defining the competencies: a) based on personality parameters; b) based on the performance of tasks and activities; c) based on the performance of production activities; d) based on performance management. Each of the four competency models leads to different approaches to planning, organizing, and personnel management.

\section{Balanced scorecard as an innovative technology}

According to the experience, a balanced scorecard [15] developed as the personal balanced scorecard in terms of HEI management is the effective mechanism for HEI management and competitiveness improvement. Such an individual system makes it possible to consider the performance indicators of an organization and a person as an interconnected complex. A Personal Balanced Scorecard is currently considered as an effective method for coaching (mentoring, work with employees, including individual training and counseling) [16]. 
The special role of this method is to change the behavior of the educator in order to increase the efficiency of the HEI. The Personal Balanced Scorecard is considered as an integral part of the Total Performance Scorecard [17], which in turn includes the Organization Balanced Scorecard, talent management, Total Quality Management, and the Personal Balanced Scorecard indicators.

In its ideology, the concept of a Total Performance Scorecard can be considered a systematized process of continuous, step-by-step learning and development aimed at forming the competitiveness of both the individual and the personnel of the organization as a whole. The main components of this process - improvement, development, learning - are closely related and must balance each other.

The Balanced Scorecard is an innovative technology, as the set of indicators provides a synergistic effect, which is a characteristic of both novation and innovation.

\section{Bimodal educational systems}

Distance education and its methods become increasingly popular in modern education. Expanding the field of education requires the use and improvement of distance education methods. Some educational institutions practice only distance learning, others practice a combination of traditional and distance education (blended learning). The latter are called bimodal educational systems. In bimodal systems, distance education is integrated into the structure of the traditional educational model. Full-time and distance students can study with the same teachers, according to the same programs, and take the same, or similar, exams. As a matter of fact, "traditional" students often use teaching materials aimed at distance-learning students. In bimodal systems, teachers often assume the functions that are assigned to collectives in specialized systems.

In most bimodal educational organizations, distance education is managed and administered by a dedicated department of the organization. Compared to specialized systems, bimodal distance learning systems are used in a small area as a rule.

Bimodal educational systems are not just an additive application of traditional and distance education methods, but an optimal combination of technologies based on the specifics of the university and the integration of its academic disciplines. It is these systems that provide a synergistic effect and are innovative.

\section{DISCUSSION}

It is misguided to reduce innovation management only to the creation of technological innovations. The innovativeness of an educational organization as the basis for obtaining innovations and innovative methods in education is a more important indicator.

Innovation includes innovation potential and innovative resources. It is necessary to distinguish between innovation potential and innovation resources. 
Innovation potential is a complex that includes the states of the elements of the innovative resource base, a set of methods and means for obtaining innovative resources and subsequent innovative activities. Assessment of innovative potential is a quantitative measure of the possibility of creating innovative resources and performing innovative activities using available innovative resources. Innovative potential serves as the basis for obtaining a resource.

Innovative resources are sources and prerequisites for obtaining innovations that can be implemented with existing technologies and socio-economic relations. An innovative resource is a set of existing relationships, means, and opportunities for creating innovations. The innovation resource serves as the basis for the implementation of innovation.

The end product of an educational institution, acting in the form of an educational service, is not only a function of the direct professional knowledge and competencies of the heads and staff of the $\mathrm{HEl}$, but an integral result of social, institutional, and other knowledge of the HEI. Therefore, the existing approaches to the management of educational knowledge are closely related to the cognitive model of the human capital of the enterprise [18].

The main functions of the educational knowledge management system are to solve two general interrelated tasks. First, to form innovative and self-learning corporate human capital, capable of high-speed creative labor, constructive "conversion". Second, to create social conditions within which corporate human capital of innovative quality can create the innovations demanded by the market and other consumers in the form of educational products.

\section{CONCLUSION}

The innovative management methods are becoming relevant for modern HEls to ensure high-quality training. The need for innovative development, changes in the organization arises in any case, regardless of the target orientation adopted by the top management. This determines the utilization of innovative management as a set of measures to increase the competitiveness of education and improve the quality of it. Innovation is associated with the use of advanced methods and technologies and increases the level of education at the HEI. It is required to distinguish the $\mathrm{HEI}$ management and the knowledge transfer management. The basis of all of this is the concept of information units and integrated information technology. Moreover, the information resources for educational tasks are being organized in a new way. They are more structured and shaped using cognitive models. However, not all uses of information technology, management technology, bimodal systems, and virtual learning systems are innovative. They become such only when a synergistic effect is obtained. 


\section{REFERENCES}

1. Ozhereleva, T.A. (2013). Management of educational innovations. Distance and Virtual Learning, 4, 104-108.

2. Advanced Micro-Electronics, Inc. (n.d.). The Top 6 Technology Innovations for Education. Retrieved May 29, 2021, from https://www.theamegroup.com/top-6-technologyinnovations-education/

3. Springwise Intelligence. (2020). Top 7 Education Innovations From 2020. Retrieved May 29, 2021, from https://www.springwise.com/innovation-snapshop/educationsolutions-2020

4. Organisation for Economic Co-operation and Development. (2004). The Measurement of Scientific and Technological Activities. Proposed Guidelines for Collecting and Interpreting Technological Innovation Data. Oslo Manual. Organisation for Economic Co-operation and Development. 2004. 93p.

5. Tsvetkov, V.Ya. Innovations analysis in terms of OECD standards. European Researcher, 31(10-1), 1689-1693.

6. Tsvetkov, V.Ya., Skuratov, A.K., Zakharevich, E.E., Zakharova, O.K., Derbeneva, O.Yu., Popova, I.A., Ruzanova, N.S., Kostyukevich, S.Kh. \& Soldatenoko, I.S. (2009). Information Technologies in University Management: A Collection of Analytical Materials on the ICT4UM Project. Tver: Tver State University.

7. Sharma, M.K., \& Sharma, R.C. (2021). Innovation framework for excellence in higher education institutions. Global Journal of Flexible Systems Management, 22, 141-155. https://doi.org/10.1007/s40171-021-00265-x

8. Kravchenko, O. I., Tymchuk, D. S., Pavlysh, T. H., Kyslenko, D. P., \& Lutsenko, O. V. (2020). Educational management of innovative pedagogical process in higher education institutions (HEls). International Journal of Higher Education, 9(7), 1-11. https://doi. org/10.5430/ijhe.v9n7p1

9. Zabolotniaia, M., Cheng, Z., Dorozhkin, E.M., \& Lyzhin, A.I. (2020). Use of the LMS Moodle for an effective implementation of an innovative policy in higher educational institutions. International Journal of Emerging Technologies in Learning, 15(13), 172189. https://doi.org/10.3991/ijet.v15i13.14945

10. Toetenel, L. (2014). Social networking: a collaborative open educational resource. Computer Assisted Language Learning, 27(2), 149-162. DOI: 10.1080/09588221.2013.818561

11. Martindale, T., Cates, W.M., \& Qian, Y. (2004). Analysis of recognized web-based educational resources. Computers in the Schools, 21(3-4), 101-117. DOI: 10.1300/ J025v21n03_11

12. Pushkareva, K.A. (2010). Model of the formation of the competitiveness of the organization's personnel. Bulletin of the Moscow Regional Pedagogical University. 
Series Economics, 2, 113-117.

13. Gurbuz, S., \& Mert, I.S. (2011). Impact of the strategic human resource management on organizational performance: evidence from Turkey. The International Journal of Human Resource Management, 22(8), 1803-1822. DOI: 10.1080/09585192.2011.565669

14. Gusakovsky, M.A. (2007). Innovative educational program of the university and the quality system. In Collection of Articles of International Scientific-Practical Conference "Quality Management of Higher Education in the Transition to a Two-Stage System of Training": Minsk, June 6-7, 2007 (pp. 44-48). Minsk: BSU.

15. Pushkareva, K.A. (2013). Application of individual balanced indicators for university management. Distance and Virtual Education, 6, 114-121.

16. Mamabolo, A., \& Myres, K. (2020). Performance measurement in emerging market social enterprises using a balanced scorecard. Journal of Social Entrepreneurship, 11(1), 65-87 DOI: 10.1080/19420676.2018.1561499

17. Rampersad, H. (2005). Total performance scorecard: The way to personal integrity and organizational effectiveness. Measuring Business Excellence, 9, 21-35. DOI: 10.1108/13683040510616943.

18. Bolbakov, R.G. (2014). Analysis of cognitiveness in science and education. Perspectives of Science and Education, 10 (4), 15-19.

\section{INFORMATION ABOUT THE AUTHOR}

Andrey A. Maiorov - Professor, Doctor of Technical Sciences, Head of the Department of Information and Measuring Systems. Moscow State University of Geodesy and Cartography. E-mail: miigaiknir@yandex.ru. ORCID: 0000-0001-5539-3719. Researcher ID: I-5667-2018. Scopus ID: 57195372649

\section{(9) (1) ( ) \\ open 2 access}

Available: https://statecounsellor.wordpress.com/2021/05/30/maiorov/

Received: Feb 5, 2021 | Accepted: May 14, 2021 | Published: Jun 1, 2021

Editor: Santosh K. Behera, PhD, Sidho-Kanho-Birsha University, INDIA

Copyright: (c) 2021 Maiorov, A. This is an open access article distributed under the terms of the Creative Commons Attribution License, which permits unrestricted use, distribution, and reproduction in any medium, provided the original author and source are credited.

Competing interests: The authors have declared that no competing interests exist. 